\title{
Dijital Platformlarda Motivasyon ve Öz-düzenlemeli Öğrenmea
}

\author{
Nurcihan Yürük ${ }^{a}$
}

\section{Özet}

Bu çalışmanın amacı, öz-düzenlemeli öğrenme stratejisi kullanımı ile çevrimiçi öğrenme motivasyonu arasındaki ilişkiyi belirlemek ve ayrıca öz-düzenlemeli öğrenme stratejilerinin çevrimiçi öğrenme motivasyonunda yordayıcı bir rolü olup olmadığını araştırmaktır. Araştırmada iki ölçek kullanılmıştır. İlk ölçek Dündar ve Köksal (2017) tarafından yabancı dil öğrenenlerin strateji tercihlerini belirlemek için, ikinci ölçek ise Özbaşı, Cevahir ve Özdemir (2018) tarafından öğrencilerin çevrimiçi öğrenmeye yönelik motivasyon kaynaklarını belirlemek için geliştirilmiştir. Selçuk Üniversitesi'nden 125 katılımcı ile çevrimiçi bir araştırma yürütülmüştür. Elde edilen sonuçlara göre Bilişsel Stratejiler, Duyuşsal Stratejiler, Meta Bilişsel Stratejiler, Meta-Duygusal Stratejiler yüksek düzeyde ve öğrenciler tarafından daha çok kullanılmaktadır. Ayrıca, sonuçlar öğrencilerin en çok Bilmek için İçsel Motivasyonu ( $X=22.79)$ kullandıklarını göstermiştir. Öz düzenlemeli öğrenme stratejilerinin çevrimiçi öğrenme ortamındaki motivasyonu anlamlı düzeyde yordadığı belirlenmiştir.
Anahtar Kelimeler

Öz-düzenlemeli Öğrenme Modeli

Öğrenme Stratejileri

Motivasyon

Çevrimiçi Öğrenme

Makale Hakkında

Geliş Tarihi: 28.06.2021

Kabul Tarihi: 24.09.2021

Doi: 10.18026/cbayarsos.958579

\section{Motivation and Self-Regulated Learning in Digital Platforms}

\section{Abstract}

The purpose of this study is to determine the relationship between selfregulated learning strategy use and online learning motivation and also investigate whether self-regulated learning strategies have a predictive role in online learning motivation. Two scales were used in the study. The first scale was developed by Dündar ve Köksal (2017) to identify L2 learners' strategy preferences and the second scale was developed by Özbaşı, Cevahir and Özdemir (2018) to determine students' motivation sources for online learning. An online survey was conducted with 125 participants at Selçuk University. According to results, Cognitive Strategies, Affective Strategies, Meta Cognitive Strategies, Meta-Affective Strategies related were at a high level and used more by students. In addition, the results showed that students mostly used Intrinsic Motivation to Know ( $X=22.79)$. It was determined that self-regulated strategies significantly predicted motivation in the online learning environment.
Keywords

Self-regulated Learning Model Learning Strategies

Motivation

Online Learning

\section{About Article}

Received: 28.06.2021

Accepted: 24.09 .2021

Doi: 10.18026/cbayarsos.958579

a İletişim Yazarı: nurcihanbasibek@yahoo.com

Selçuk Üniversitesi, Mütercim ve Tercümanlık Bölümü, İngilizce Mütercim ve Tercümanlık A.B.D., ORCID: 0000-0001-8889-8107. 


\section{Introduction}

Language learning strategy (LLS) has contributed much to language proficiency in the past 40 years (O'Malley \& Chamot, 1990; Oxford, 2011; Platsidou \& Kantaridou, 2014; Platsidou, \& Sipitanou, 2014), in addition the different factors influencing strategy use such as learner characteristics like gender, level of competence, motivation, self-efficacy beliefs and learning styles. Individual differences as "language aptitude, motivation, learning style, self-esteem, anxiety, learner's belief and creativity" affect second language acquisition (Dörnyei, 2005, p.106). Oxford (1990) states "more highly motivated learners use a significantly greater range of appropriate strategies than do less motivated learners" (p.13).

"According to self-determination theory, there are two general types of motivation, one based on intrinsic interest in the activity per se and the other based on rewards extrinsic to the activity itself. These types of motivation are not categorically different, however, but rather lie along a continuum of selfdetermination"(Noel, Pelletier \& Vallerand, 2000, p. 60).

The acquisition and development of competence are to a large extent bound up with motivational factors, which is why the problem of motivation has always aroused great interest among psychologists and educators (Dewey, 1913; Fischer, 1912; Herbart, 1965; Lunk, 1926). Even if we could reliably prove the obvious effect of motivation on learning outcomes, it is not clear how cognitive processes affect the level of motivation leading to learning and competence acquisition.

Before looking for the connection between learning and motivation, we need to build a reasonable theoretical model of how motivation affects learning. Only then we could know which variables need to be measured and which processes need to be checked. Otherwise, we can choose the experiment we want to run at will without having to lay a solid foundation for the desired result. Therefore, it turns out that it is difficult to find the proposed relationship.

Self-regulated learning Model ( $\left.S^{2} R\right)$ as one of the important metacognitive processes fills this gap from a different perspective in the light of language learning strategies. In this study, first, $\mathrm{S}^{2} \mathrm{R}$ framework will be described then; the concept of motivation could be explained in terms of the framework in order to shed light on the relationship in between. Specifically, this study aims to investigate the relationship between self-regulation and motivation in online learning.

\section{Review of Literature}

Self-regulated learning (SRL) refers to "learning that occurs largely from the influence of student's self-generated thoughts, feelings, strategies, and behaviours, which are oriented toward the attainment of goals" (Schunk \& Zimmerman, 1998, p. viii). There is a variety of conceptualizations of "academic self-regulation", some researchers have determined social cognitive models of self-regulated learning in order to analyse learner success in online education (Boekaerts, Pintrich, \& Zeidner, 2000), as, social cognitive models focus on significant learning strategies and motivational factors "which could be useful for learners in these highly autonomous learning settings" (Lynch, 2003; Niemi, Nevgi, \& Virtanen, 2003; Whipp \& Chiarelli, 2004). Also, some researchers investigate the relationship between selfregulation and academic achievement. The study of Pintrich and De Groot (1990) showed that there was a positive correlation between learners' achievement levels and self-regulation 
levels. There were some other investigations that indicate the effect of motivation learning on self-regulated learning. Pintrich's (2005) study demonstrates that "effective and less effective self-regulated learners differ in several motivational processes" (p. 470). Similarly, Schunk (2005) concluded, "Students with greater personal interest in a topic and those who view the activity as important or useful are more likely to use adaptive self-regulatory strategies" (p. 87). Some studies reveal there was a positive relationship between students' academic selfefficacy and their use of SRL strategies (Pintrich \& De Groot, 1990; Schunk, 2005). In addition, in a review of past research, Schunk (2005) indicated that "highly self-regulated learners tend to report higher levels of academic self-efficacy than do students with poorer self-regulatory skills" (p. 89).

\section{Theoretical Framework of Self-regulated learning Model (S'R)}

Training autonomous learners who regulate their own learning is one of the latest trends in the past two decades. Nowadays, the teacher-centred approach has been replaced by the student-centred, so learner roles and responsibilities have become more and more important and have changed from passive to active. Students use different types of strategies to regulate their learning. Some researchers have tried to change the place of this "strategic framework with the concept of self-regulation originally come from educational psychology" (Banisaeid \& Huang, 2015, p.37; Dörnyei 2005; Rose, 2012; Tseng, Dörnyei \& Schmitt, 2006).

Zimmerman (1989) defines self-regulation as "the degree to which students become metacognitive, motivational, and behavioural participants in their learning process" (p. 329). The broader concept of self-regulation is used due to the fussiness of definition and measurement and it has been used as "a substitute for language learning strategies" in some studies (Banisaeid \& Huang, 2015, p. 38; Dörnyei, 2005; Tseng et al., 2006; Rose, 2012). Individual differences in students' language skills, motivation, learning styles, self-esteem, anxiety, beliefs and creativity will affect their second language learning (Dörnyei, 2005). Oxford (1990) believes that "more motivated students use much greater strategies than those who are less motivated" (p. 13). Self-regulated learning (SRL) includes "cognitive, metacognitive, behavioural, motivational, and emotional aspects of learning" (Panadero, 2017, p.1). A considerable number of variables that influence learning are studied within a comprehensive and holistic approach under this framework, such as self-efficacy, volition, cognitive strategies. Therefore, SRL has become one of the most important research fields in the field of educational psychology.

Language learning strategy use has contributed much to researches related to language proficiency for more than 40 years with the influence of some parameters that influence strategy use like learner characteristics such as competence, learning styles, self-efficacy and motivation (Gavriilidou \& Papanis, 2010; Green \& Oxford, 1995; O'Malley \& Chamot, 1990; Oxford \& Burry-Stock, 1995; Oxford \& Nyikos, 1989; Psaltou-Joycey, 2003; Psaltou-Joycey \& Kantaridou, 2009; Platsidou \& Kantaridou, 2014). However, language learning strategy has left its stage to the concept of self-regulation because "locating learning strategies on just behavioural and mental levels is not justifiable" (Pintrich, 2005, p.456).

Language learning strategy framework was criticised from various perspectives. First, the definitions of taxonomies are ambiguous. It is impossible to accept all the strategies as learning strategies. Second criticism is related to overgeneralize strategy use to all aspects of language teaching (Rose, 2012, p.138). In addition, Dörnyei (2005) criticised the framework 
because for Dörnyei "individual learner differences, tasks and learning situations are neglected and especially for SILL" (p.198). It has just focused on the frequency of strategy use. Therefore, the concept of self-regulation has become popular and taken the place of learning strategies. Also, some researchers think that learning strategies need some reformulation and reconceptualization (Rose, 2012; Gu, 2012).

Self-regulation is a "multidimensional construct including cognitive, metacognitive, motivational, behavioural and environmental processes that learners can apply to enhance academic achievement" (Dörnyei, 2005, p.191). Zimmerman and Schunk describes selfregulation as a "self-directive process through which learners transform their mental abilities into task-related academic skills" (2001, p.1). Self-regulation refers to "the ability of learners to manage their learning process, monitor their progress and assess their performance within this context" (Zimmerman \& Schunk, 2001, p. 2); it has the characteristic of autonomous and self-determined learning.

In consideration of these criticisms, Oxford reformulated language learning strategy incorporating with the concept of self-regulation and proposed Strategic Self-Regulation (S2R) Model (Oxford, 2011). The $S^{2} R$ framework embodies both strategies and metastrategies. Oxford (2011) states "the concept of metastrategies is more than just that of metacognitive strategies alone" (p. 157) and it reflects the multidimensional reality of the L2 learner:

Metacognitive simply means "beyond the cognitive" and includes strategies that provide general regulation (control) of cognitive strategies. Unfortunately, prior typologies of strategies had no term to describe control of three other key dimensions of L2 learning strategies: (a) the motivational dimension, (b) the social dimension, and (c) the affective dimension. The S2R Model fills this major gap by including metamotivational, metasocial, and meta-affective strategies, respectively. I feel no thrill in creating new terms, but the term metacognitive could not meaningfully be stretched; other, parallel terms were needed for non-cognitive domains" (Oxford, 2017, p.158).

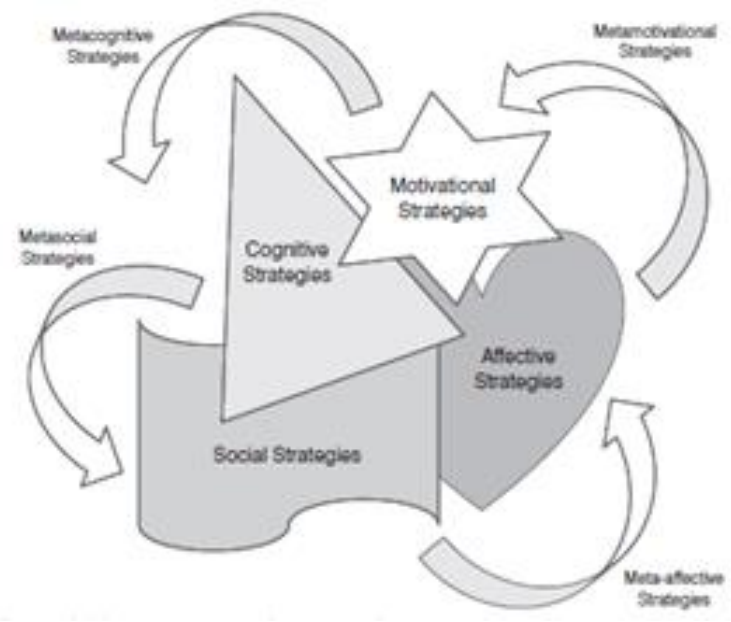

Figure 1. Metastrategies as the Overarching Guides (Oxford, 2017, p.161)

In this figure, four general types of strategies - cognitive, motivational, affective, and social have distinct shapes but are intentionally shown as overlapping, as they do in reality. In addition, each general type of strategy is cared for and guided by an arrow representing the 
relevant metastrategies (metacognitive, metamotivational, meta-affective, and metasocial, respectively). Together the metastrategies and strategies comprise a well-operating learning subsystem, which interacts with many other learning subsystems Metastrategies have the role of "executive functions," such as planning, with reference to four human learning domains: cognitive (metacognitive strategies), motivational (metamotivational strategies), social (metasocial), and affective/emotional (meta-affective strategies). These roles are:

- paying attention;

- planning;

- organizing learning and obtaining resources;

- monitoring and evaluating (Oxford, 2017, p.160).

Metastrategies, by virtue of their "executive control and management function", help the learner know whether and how to deploy a given strategy and aid in determining whether the strategy is working or has worked as intended. Strategies and metastrategies in the S2R Model are "highly dynamic, because they respond to changing needs of the learner for varying purposes in different sociocultural contexts" (Oxford, 2017, p.160). Metastrategic regulation is the learner's use of metastrategies of any kind (metacognitive, meta-affective, etc.) for the purpose of SRL. This is an expansion of Flavell's (1978) term "metacognitive regulation to identify the use of metacognitive strategies" (p.215).

\section{Motivation and Online Education}

Paris and Turner (1994) described motivation as "the engine of learning" (p.223). Motivation opportunities affect "what we learn, how we learn, and how long we learn" (Schunk \& Usher, 2012, p.17). Research shows that motivated students are more likely to perform challenging tasks. They actively participate, enjoy, fun and enterprising, and show better performance, perseverance and creativity (Ryan \& Deci, 2000). When the significant relationship between learning and motivation is taken into consideration, it is not surprising that there are many researches about motivation in various learning settings (Schunk, Meece \& Pintrich, 2014). Even so, there have been a limited number of studies about the effect of motivation on learning in online learning environment.

\section{Motivation}

Brophy (2010) defines motivation as "a theoretical construct to explain the initiation, direction, intensity, persistence, and quality of behaviour, especially goal-directed behaviour" (p. 3). It is the impetus for a purpose of action involving intentions for goals. In consideration of this definition, motivation is a process rather than a product. In terms of measurement of motivation, it has some implications. It is impossible to observe it directly so, such actions like choice of tasks, effort, achievement and persistence should be interpreted. Judgements related to motivation connect individuals' cognitive and affective processes like thoughts, beliefs, goals and emotions (Schunk, et al., 2014). They also focus on the relationship between the learner and the learning setting that is under the influence of some contextual and social considerations (Schunk, et al., 2014).

There has been a disposition to accept a limited view of motivation from current research that does not acknowledge the complicatedness and dynamic interaction of factors underlying and affecting motivation to learn. Instead, it has received attention to design motivating learning environments (Keller, 2010). Motivation was seen as a relatively stable 
characteristic, and studies focused on identifying lists of characteristics of successful students (Yukselturk \& Bulut, 2007). Studies comparing online and on-campus learners by using this approach are prevalent (Wighting, Liu, \& Rovai, 2008). According to the results of these studies, online learners are intrinsically more motivated than on-campus ones.

Nevertheless, the study of Park and Choi (2009) showed that "leaners' dropout rates were higher during online courses compared with face to face courses" (p. 213). There may be many underlying reasons of this interruption from online courses like "anxiety or frustration with technology, the feeling of aloneness or time pressure or any other burdens that decrease the motivation of the learner" (Artino, 2008, p. 263). Therefore, motivation is one of the most important factors that affect the achievement level of the learners during online learning process. In the light of these factors, it is needed to think thoroughly the role and position of the motivation in online settings. So, in order to understand this, it is necessary to give a clear definition of online learning.

\section{Online learning}

There are many terms to describe learning and teaching through digital tool like e-learning, online learning, distance education, flipped learning, blended learning and Massive Open Online Courses (MOOCs). In order to make sense of these terminologies Nichols (2008) used the term $e$-learning to define "any application on the continuum of technology from face-toface to distance settings" (http://akoaotearoa.ac.nz/project/eprimer-series/resources/files/elearning-context-1-eprimer-series).

There are many definitions of online learning and all these definitions display the variety of practice and technologies in use. Ally (2008) goes on to define it in the following way:

"... the use of the internet to access materials; to interact with the content, instructor, and other learners; and to obtain support during the learning process, in order to acquire knowledge, to construct personal meaning, and to grow from the learning experience" (p. 5).

Namely, online learning is accepted as a form of distance education mediated by technological aids where students are physically separated from the teacher. Some aspects related to personality like "independence, self-direction and intrinsic motivation are the important issues affiliated with distance learners" (Moore, 1989, p. 5). Especially, intrinsic motivation is accepted among the important characteristics of online learners (Shroff, Vogel, Coombes, \& Lee, 2007). In online learning settings, "learners are expected to be intrinsically motivated, as such a learning environment mostly depend on intrinsic motivation in addition to self-regulation" (Martens, Gulikers \& Bastiaens, 2004, p.370). While intrinsic motivation of learners is essential, current research studies on motivation in these settings have been restricted in both number and scope (Bekele, 2010).

\section{Purpose of the Study}

The purpose of this study is primarily to determine the relationship between self-regulated learning and motivation in online settings. In addition, this study will explore self-regulated strategy preferences of translation and interpretation students. Also, common motivational orientation will be identified. These relations are investigated according to variables; gender, grades and academic achievement of translation and interpretation students. 


\section{Research questions}

1) What are the most frequent self-regulated learning strategies used by students?

2) Is there a relationship between self-regulated learning strategy uses of students according to
a. their gender?
b. their academic achievement?
c. their grades?

3) What motivational orientation is common among students?

4) Is there a relationship between online learning motivations of students according to
a. their gender?
b. their academic achievement?
c. their grades?

5) Do self-regulation strategies predict online learning motivation?

\section{Methodology}

It is assumed that the relationship between motivation and academic achievements of learners are influenced by use of self-regulated learning strategies that are significantly associated with the increase of motivation.

\section{Instruments}

The first scale used in this study was developed by Dündar ve Köksal (2017). The overall reliability of the model Cronbach's alpha statistic is 0.85 . The scale can be used to identify L2 learners' strategy preferences and to what extent they use them in any educational settings. It is a 4-point Likert-type scale. The scale is composed of 35 items embedded in 6 subdimensions: "Cognitive Strategies, Affective Strategies, Socio-Cultural Interactive Strategies, Meta-Cognitive Strategies, Meta-Affective Strategies, and Meta-Sociocultural interactive Strategies".

The second scale used in this study was developed by Özbaşı, Cevahir and Özdemir (2018) to determine students' motivation sources for online learning. There are 28 items in the scale in total. The scale consists of "intrinsic motivation to know, intrinsic motivation to succeed, intrinsic motivation to experience stimulation, determined regulation, reflected regulation, external regulation and amotivation". The scale's Cronbach's alpha coefficients calculated at each sub-dimension level are between 0.60 and 0.90 . It is a 7-point Likert type scale consisting of 28 items.

\section{Subjects}

The study was conducted using an online survey that was correctly completed by 1st, 2nd, and 3rd students from Translation and Interpretation Department at Selçuk University. These students have attended online courses at their department for three terms. All the courses and examinations they get have been carried out in an online setting. The respondents were asked to answer two different scales about self-regulated learning and 
online learning motivation. The study group of the research consisted of 125 students. Demographic information about the students is given in the Table 1.

Table 1. Analysis For Demographic Information

\begin{tabular}{llll}
\hline Demographic Information & Categories & f & \% \\
\hline \multirow{2}{*}{ Gender } & Female & 82 & 65.6 \\
& Male & 43 & 34.4 \\
Grade & Grade 1 & 57 & 45.6 \\
& Grade 2 & 28 & 22.4 \\
& Grade 3 & 40 & 32.0 \\
& $1.51-2.00$ & - & - \\
Academic Achievement & $2.01-2.50$ & - & - \\
& $2.51-3.00$ & 23 & 18.4 \\
& $3.01-3.50$ & 83 & 66.4 \\
\hline
\end{tabular}

According to Table 1, $82(65.6 \%)$ female students and $43(34.4 \%)$ male students were participated in the study. $57(45.6 \%)$ of the participants were in the 1st grade, 28 of them (422.4) were in the 2 nd grade, 40 of them (32.0\%) were in the 3rd grade. Considering their academic achievement, there were no students with an academic average of 1.51-2.00 and 2.01-2.50, $23(18.4 \%)$ had an academic average of 2.51-3.00, $83(66.4 \%)$ had an academic average of 3.01-3.50 and 19 (15.2\%) were 3.51-4.00.

In order to analyse whether self-directed learning and online learning motivation change according to gender variable in the online learning environment, t-test was conducted. Also, Kruskal Wallis $\mathrm{H}$ test was used to determine whether there was a significant difference according to grade and academic achievement. Regression analysis was conducted to determine the level of self-directed learning and online learning motivation in an online learning environment.

The scores of the students for self-regulated strategies in online learning were calculated as follows. This tabular was created because there was not an equal distribution among the items belonging to some sub-dimensions in the scale in terms of number.

\begin{tabular}{llll}
\hline Intervals of Score & Low & Medium & High \\
Cognitive Strategies & $3-5$ & $6-8$ & $9-12$ \\
Affective Strategies & $3-5$ & $6-8$ & $9-12$ \\
Socio-Cultural Interactive Strategies & $5-9$ & $10-14$ & $15-20$ \\
Meta Cognitive Strategies & $9-17$ & $18-26$ & $27-36$ \\
Meta-Affective Strategies & $10-19$ & $20-29$ & $30-40$ \\
Meta- Socio-Cultural Interactive Strategies & $5-9$ & $10-14$ & $15-20$ \\
\hline
\end{tabular}




\section{Findings}

1) What are the most frequent self-regulated learning strategies used by students?

Table 2. Descriptive Analysis Results of Students' Tendencies to Use Self-regulated Strategies in Online Learning

\begin{tabular}{llll}
\hline Dimension & $\mathbf{N}$ & $\mathbf{X}$ & $\mathbf{S S}$ \\
Cognitive Strategies & 125 & 9.21 & 1.80 \\
Affective Strategies & 125 & 9.18 & 1.61 \\
Socio-Cultural Interactive Strategies & 125 & 11.56 & 2.16 \\
Meta Cognitive Strategies & 125 & 29.80 & 3.81 \\
Meta-Affective Strategies & 125 & 27.59 & 5.20 \\
Meta- Socio-Cultural Interactive Strategies & 125 & 14.85 & 2.80 \\
\hline
\end{tabular}

When students' tendencies to use self-regulated strategies in online learning are examined, it was found that Cognitive Strategies $(X=9.21)$, Affective Strategies $(X=9.18)$, Meta Cognitive Strategies $(X=29.80)$ and Meta-Affective Strategies $(X=27.59)$ were at a higher level than the average. Socio-Cultural Interactive Strategies $(X=11.56)$ and Meta-Socio-Cultural Interactive Strategies $(X=14.85)$ were at a medium level according to the average.

According to these average scores, Cognitive Strategies, Affective Strategies, Meta Cognitive Strategies, Meta-Affective Strategies related to the use of self-regulation strategies were at a high level and they used more; Socio-Cultural Interactive Strategies and Meta-Socio-Cultural Interactive Strategies were at a medium level and it can be said that they are used less than other strategies.

2) Is there a relationship between self-regulated learning strategy uses of students according to:

\section{a. gender?}

Table 3. Descriptive Analysis Results of The Relationship between The Self-Regulated Strategies of Students and Their Gender

\begin{tabular}{lllllll}
\hline & Gender & $\mathbf{N}$ & $\mathbf{X}$ & SS & $\mathbf{t}$ & $\mathbf{p}$ \\
Cognitive Strategies & Female & 82 & 9.21 & 1.80 & & \\
& Male & 43 & 9.20 & 1.81 & .007 & .99 \\
Affective Strategies & Female & 82 & 9.24 & 1.61 & & \\
& Male & 43 & 9.06 & 1.62 & .585 & .56 \\
Socio-Cultural Interactive Strategies & Female & 82 & 11.3 & 2.25 & & \\
& Male & 43 & 11.1 & 1.99 & .534 & .59 \\
Meta Cognitive Strategies & Female & 82 & 30.7 & 3.40 & & \\
\multirow{2}{*}{ Meta-Affective Strategies } & Male & 43 & 28.7 & 4.34 & 2.42 & .02 \\
& Female & 82 & 28.5 & 4.82 & 1.42 & .15 \\
\hline
\end{tabular}




\begin{tabular}{|c|c|c|c|c|c|c|c|}
\hline & & Male & 43 & 26.7 & 5.85 & & \\
\hline \multirow{2}{*}{$\begin{array}{l}\text { Socio-Cultural } \\
\text { s }\end{array}$} & \multirow[t]{2}{*}{ Interactive } & Female & 82 & 15.8 & 2.63 & \multirow{2}{*}{3.76} & \multirow{2}{*}{.00} \\
\hline & & Male & 43 & 13.0 & 2.74 & & \\
\hline \multirow{2}{*}{ Total } & & Female & 82 & 1040 & 10.35 & \multirow{2}{*}{2.55} & \multirow{2}{*}{.01} \\
\hline & & Male & 43 & 98.5 & 12.79 & & \\
\hline
\end{tabular}

Table 3 showed the relationship between students' self-regulated strategies in online learning and their gender. Accordingly, no significant difference was determined between the four sub-dimensions and gender (Cognitive Strategies $(t=.007 ; p>.05)$; Affective Strategies $(t=.585 ; \mathrm{p}>.05)$; Socio-Cultural Interactive Strategies $(t=.534 ; \mathrm{p}>.05)$; MetaAffective Strategies $(\mathrm{t}=1.4 ; \mathrm{p}>.05)$ However, a significant difference was determined between two sub-dimensions and gender (Meta Cognitive $(t=2.42 ; \mathrm{p}<.05)$. ); Meta-SocioCultural Interactive Strategies $(t=3.76 ; p<.05)$. A significant difference was determined between self-regulation total score and gender $(t=2.55 ; \mathrm{p}<.05)$.

A significant difference was determined between gender and Meta Cognitive Strategies, Meta-Socio-Cultural Interactive Strategies and total score, which are sub-dimensions of selfregulated strategies in online learning, and it was determined that female students used these sub-factors more intensely than male students.

\section{b. academic achievement?}

Table 4. Descriptive Analysis Results of The Relationship between Students' SelfRegulated Strategies in Online Learning and Academic Achievement

\begin{tabular}{|c|c|c|c|c|c|c|}
\hline & & $\begin{array}{l}\text { Sumof } \\
\text { Squares }\end{array}$ & sd & $\begin{array}{l}\text { Mean } \\
\text { Square }\end{array}$ & F & $\mathrm{p}$ \\
\hline \multirow[t]{3}{*}{$\begin{array}{l}\text { Cognitive } \\
\text { Strategies }\end{array}$} & $\begin{array}{r}\text { Between } \\
\text { Groups }\end{array}$ & 9.87 & 2 & 4.93 & & \\
\hline & $\begin{array}{l}\text { Within } \\
\text { Groups }\end{array}$ & 403.42 & 122 & 3.22 & 1.53 & .22 \\
\hline & Total & 413.30 & 124 & & & \\
\hline \multirow[t]{3}{*}{ Affective Strategies } & $\begin{array}{r}\text { Between } \\
\text { Groups }\end{array}$ & 12.50 & 2 & 6.25 & & \\
\hline & $\begin{array}{l}\text { Within } \\
\text { Groups }\end{array}$ & 319.00 & 122 & 2.55 & 2.44 & .09 \\
\hline & Total & 331.50 & 124 & & & \\
\hline \multirow{3}{*}{$\begin{array}{l}\text { Socio-Cultural } \\
\text { Interactive } \\
\text { Strategies }\end{array}$} & $\begin{array}{r}\text { Between } \\
\text { Groups }\end{array}$ & 33.34 & 2 & 16.67 & & \\
\hline & $\begin{array}{l}\text { Within } \\
\text { Groups }\end{array}$ & 560.15 & 122 & 4.48 & 3.72 & .03 \\
\hline & Total & 593.50 & 124 & & & \\
\hline $\begin{array}{l}\text { Meta Cognitive } \\
\text { Strategies }\end{array}$ & $\begin{array}{r}\text { Between } \\
\text { Groups }\end{array}$ & 25.26 & 2 & 12.63 & .86 & .42 \\
\hline
\end{tabular}




\begin{tabular}{|c|c|c|c|c|c|c|}
\hline & $\begin{array}{l}\text { Within } \\
\text { Groups }\end{array}$ & 1824.85 & 122 & 14.59 & & \\
\hline & Total & 1850.11 & 124 & & & \\
\hline \multirow[t]{3}{*}{$\begin{array}{l}\text { Meta-Affective } \\
\text { Strategies }\end{array}$} & $\begin{array}{r}\text { Between } \\
\text { Groups }\end{array}$ & 33.93 & 2 & 16.96 & & \\
\hline & $\begin{array}{l}\text { Within } \\
\text { Groups }\end{array}$ & 3412.93 & 122 & 27.30 & .62 & .53 \\
\hline & Total & 3446.87 & 124 & & & \\
\hline \multirow{3}{*}{$\begin{array}{l}\text { Meta- Socio- } \\
\text { Cultural } \\
\text { Interactive } \\
\text { Strategies }\end{array}$} & $\begin{array}{r}\text { Between } \\
\text { Groups }\end{array}$ & 6.25 & 2 & 3.12 & & \\
\hline & $\begin{array}{l}\text { Within } \\
\text { Groups }\end{array}$ & 991.92 & 122 & 7.93 & .39 & .67 \\
\hline & Total & 998.18 & 124 & & & \\
\hline \multirow[t]{3}{*}{ Total } & $\begin{array}{r}\text { Between } \\
\text { Groups }\end{array}$ & 431.12 & 2 & 215.56 & & \\
\hline & $\begin{array}{l}\text { Within } \\
\text { Groups }\end{array}$ & 16276.17 & 122 & 130.20 & 1.65 & .19 \\
\hline & Total & 16707.30 & 124 & & & \\
\hline
\end{tabular}

According to Table 4 showing the relationship between students' self-regulated strategies in online learning and academic achievement, no significant difference was determined between the five sub-dimensions of the scale and academic achievement (Cognitive Strategies ( $\mathrm{F}=1.53 ; \mathrm{p}>.05)$; Affective Strategies $(\mathrm{F}=2.44 ; \mathrm{p}>.05))$; Meta Cognitive Strategies $(\mathrm{F}=.86 ; \mathrm{p}>$.05); Meta-Affective Strategies ( $\mathrm{F}=.62 ; \mathrm{p}>$.05); Meta-Socio-Cultural Interactive Strategies $(\mathrm{F}=.39 ; \mathrm{p}>.05$ There was a significant difference between Socio-Cultural Interactive Strategies $(\mathrm{F}=3.72 ; \mathrm{p}<.05)$ and academic achievement. As a result, there was no significant difference between self-regulation total score and academic achievement $(\mathrm{F}=1.65$; $\mathrm{p}>$.05).

A significant difference was determined between Socio-Cultural Interactive Strategies and academic achievement, and in order to define at which ranges academic achievement differs Scheffe test of Post-Hoc tests was used. It was observed that those with academic achievement between 3 (2.51-3.00) were higher than those with an academic achievement of 5 (3.51-4.00).

\section{c. their grades?}

Table 5. Descriptive Analysis Results of The Relationship between Students' SelfRegulated Strategies in Online Learning and Grades

\begin{tabular}{lllllll}
\hline & & $\begin{array}{l}\text { Sum } \\
\text { Squares }\end{array}$ & of & sd & Mean & F \\
Square & & & p \\
$\begin{array}{l}\text { Cognitive } \\
\text { Strategies }\end{array}$ & $\begin{array}{l}\text { Between } \\
\text { Groups }\end{array}$ & 1.51 & 2 & .75 & .23 & .79 \\
\hline
\end{tabular}




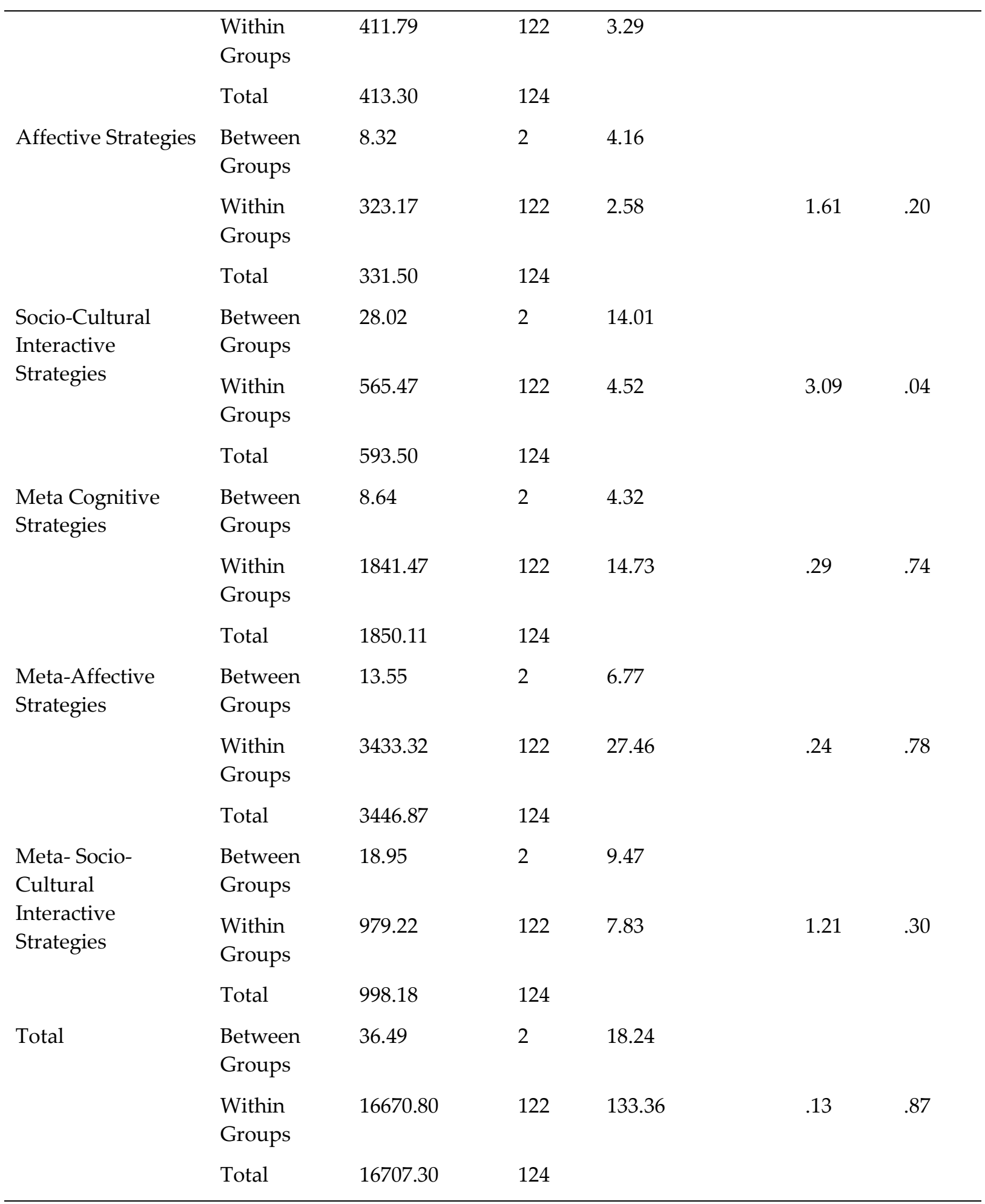

Table 5 shows the relationship between students' self-regulated strategies in online learning and their grade levels. The results indicated that no significant difference was found between Cognitive Strategies $(\mathrm{F}=.23 ; \mathrm{p}>.05)$, Affective Strategies $(\mathrm{F}=1.61 ; \mathrm{p}>.05)$; Meta Cognitive Strategies $(\mathrm{F}=.29 ; \mathrm{p}>.05)$; the Meta-Affective Strategies $(\mathrm{F}=.24 ; \mathrm{p}>.05)$ and Meta-SocioCultural Interactive Strategies $(\mathrm{F}=1.21 ; \mathrm{p}>.05)$ and grade levels. A significant difference was determined between Socio-Cultural Interactive Strategies and grade levels $(F=3.09 ; \mathrm{p}<.05)$. There was no significant difference between self-regulation total score and grade levels 
$(\mathrm{F}=.13 ; \mathrm{p}>$.05). A significant difference was determined between the Socio-Cultural Interactive Strategies sub-dimension and their grade levels. The Scheffe test, which is one of the Post-Hoc tests conducted to determine the differences according to success intervals showed that students at grade 3 were higher than those at grade 2 .

\section{3) What motivational orientation is common among students?}

Table 6. Descriptive Analysis Results of Tendencies towards Online Learning Motivation of Students

\begin{tabular}{llll}
\hline Dimension & $\mathbf{N}$ & $\mathbf{X}$ & SS \\
Intrinsic Motivation to Know & 125 & 22.79 & 4.22 \\
Intrinsic Motivation to Succeed & 125 & 18.18 & 4.72 \\
Intrinsic Motivation to Experience Stimulation & 125 & 19.80 & 4.90 \\
Determined Regulation & 125 & 21.54 & 4.41 \\
Reflected regulation & 125 & 17.40 & 6.09 \\
External Regulation & 125 & 22.05 & 4.35 \\
Amotivation & 125 & 19.40 & 5.69 \\
\hline
\end{tabular}

When the analysis to determine students' tendencies towards online learning motivation was examined, it was seen that students mostly used Intrinsic Motivation to Know $(X=22.79)$. According to the frequency of use in online learning motivation, respectively, External Regulation ( $X=22.05)$, Determined Regulation $(X=21.54)$, Intrinsic Motivation to Experience Stimulation $(X=19.80)$, Lack of Motivation $(X=19.40)$, Intrinsic Motivation to Achieve $(X=18.18)$ and Reflected Arrangement $(X=17.40)$ were preferred by the students.

4) Is there a relationship between online learning motivations of students according to

$$
\text { a. gender? }
$$

Table 7. Descriptive Analysis Results of The Relationship Between Students' Online Learning Motivation and Gender

\begin{tabular}{lllllll}
\hline & Gender & $\mathbf{N}$ & $\mathbf{X}$ & $\mathbf{S S}$ & $\mathbf{t}$ & $\mathbf{p}$ \\
& Female & 82 & 23.31 & 4.03 & & \\
Intrinsic Motivation to Know & Male & 43 & 22.09 & 4.58 & 1.28 & .20 \\
& Female & 82 & 19.08 & 4.30 & & \\
Intrinsic Motivation to Succeed & Male & 43 & 16.34 & 5.06 & 3.15 & .002 \\
& Female & 82 & 20.52 & 4.31 & & \\
Intrinsic Motivation to Experience & Male & 43 & 18.34 & 5.72 & 2.37 & .02 \\
Stimulation & Female & 82 & 22.32 & 4.17 & 2.90 & .004 \\
Determined Regulation & & & & & & \\
\hline
\end{tabular}




\begin{tabular}{lllllll}
\hline & Male & 43 & 19.95 & 4.51 & & \\
Reflected regulation & Female & 82 & 19.08 & 4.93 & 4.77 & .00 \\
& Male & 43 & 13.97 & 6.81 & & \\
External Regulation & Female & 82 & 22.50 & 4.13 & & \\
& Male & 43 & 21.14 & 4.68 & 1.64 & .10 \\
Amotivation & Female & 82 & 19.23 & 5.49 & & \\
& Male & 43 & 19.75 & 6.15 & .47 & .63 \\
Total & Female & 82 & 145.88 & 23.21 & & \\
& Male & 43 & 131.60 & 24.79 & & .002 \\
\hline
\end{tabular}

According to Table 7, Intrinsic Motivation to Know ( $t=1.28 ; \mathrm{p}>.05)$ was one of most preferred online learning motivation strategies. No significant difference was found between the external regulation $(\mathrm{t}=1.64 ; \mathrm{p}<.05)$ and Amotivation $(\mathrm{t}=.47 ; \mathrm{p}>.05)$ and gender. Intrinsic Motivation to Achieve ( $\mathrm{t}=3.15 ; \mathrm{p}<.05)$; Intrinsic Motivation to Experiencing Stimulation ( $\mathrm{t}=$ 2.37; $\mathrm{p}<.05)$ and Specified Regulation $(\mathrm{t}=2.90 ; \mathrm{p}<.05)$ and gender were significantly different. A significant difference was determined between the total score of online learning motivation and gender $(\mathrm{t}=3.15 ; \mathrm{p}<.05)$.

Significant differences were determined between gender and the sub-dimensions Intrinsic Motivation To Achieve, Intrinsic Motivation To Experiencing Stimulation, Determined Regulation, External Regulation and total score, and it was determined that female students used these more intensely than male students.

b. academic achievement?

Table 8. Descriptive Analysis Results of The Relationship Between Students' Online Learning Motivation and Academic Achievement

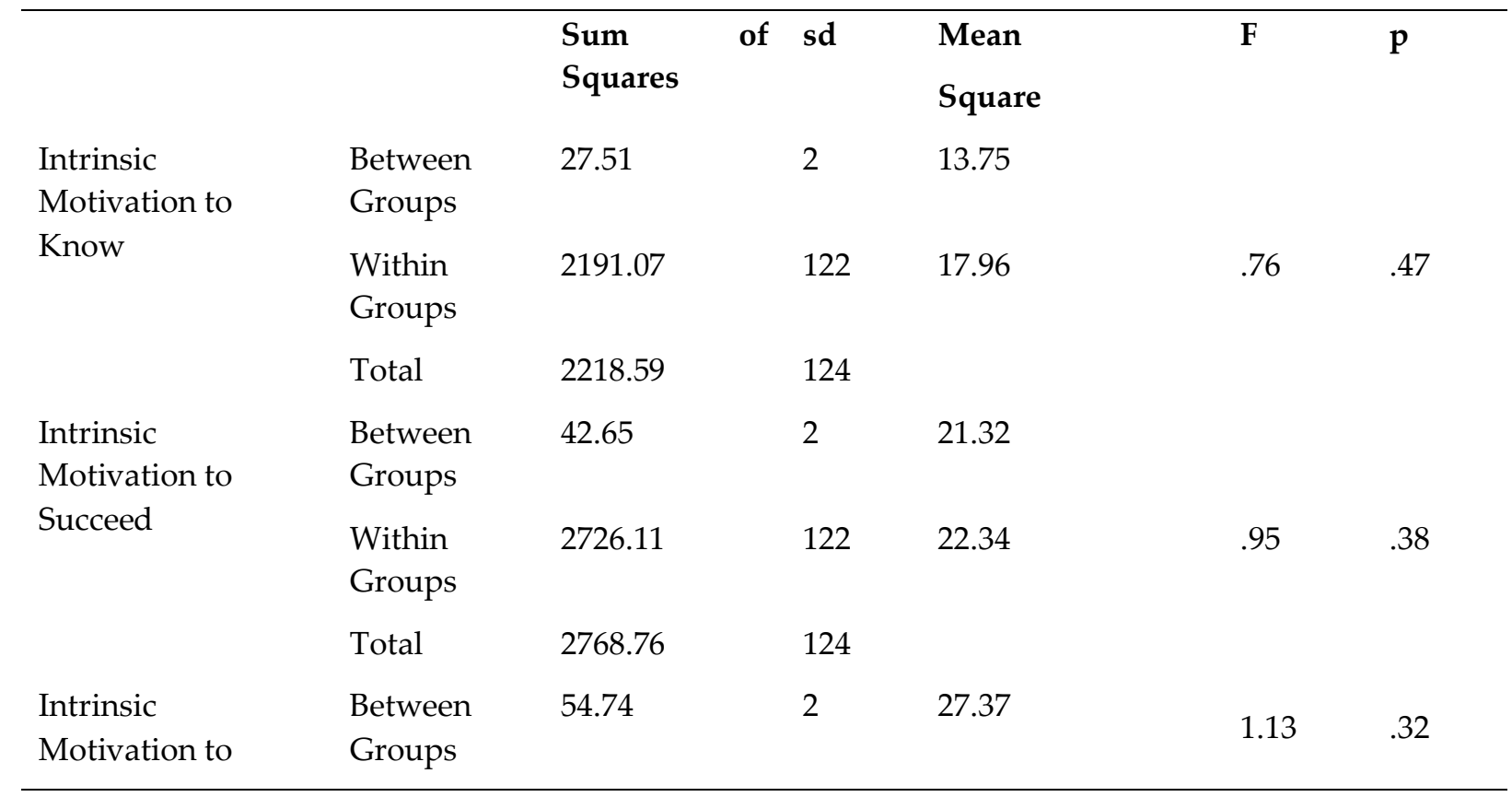




\begin{tabular}{|c|c|c|c|c|c|c|}
\hline \multirow{3}{*}{$\begin{array}{l}\text { Experience } \\
\text { Stimulation }\end{array}$} & Within & 2934.64 & 122 & \multirow[t]{3}{*}{24.05} & & \\
\hline & Groups & & & & & \\
\hline & Total & 2989.39 & 124 & & & \\
\hline \multirow{4}{*}{$\begin{array}{l}\text { Intrinsic } \\
\text { Motivation to } \\
\text { Experience } \\
\text { Stimulation }\end{array}$} & Between & 19.66 & 2 & \multirow[t]{2}{*}{9.83} & \multirow{4}{*}{.50} & \multirow{4}{*}{.61} \\
\hline & Groups & & & & & \\
\hline & Within & 2397.34 & 122 & \multirow[t]{2}{*}{19.65} & & \\
\hline & Total & 2417.00 & 124 & & & \\
\hline \multirow[t]{3}{*}{$\begin{array}{l}\text { Reflected } \\
\text { regulation }\end{array}$} & $\begin{array}{l}\text { Between } \\
\text { Groups }\end{array}$ & 40.64 & 2 & 20.32 & \multirow{3}{*}{.54} & \multirow{3}{*}{.58} \\
\hline & $\begin{array}{l}\text { Within } \\
\text { Groups }\end{array}$ & 4559.54 & 122 & \multirow[t]{2}{*}{37.37} & & \\
\hline & Total & 4600.19 & 124 & & & \\
\hline \multirow[t]{3}{*}{$\begin{array}{l}\text { External } \\
\text { Regulation }\end{array}$} & $\begin{array}{l}\text { Between } \\
\text { Groups }\end{array}$ & 185.95 & 2 & 92.97 & \multirow{3}{*}{5.25} & \multirow{3}{*}{.006} \\
\hline & $\begin{array}{l}\text { Within } \\
\text { Groups }\end{array}$ & 2160.65 & 122 & \multirow[t]{2}{*}{17.71} & & \\
\hline & Total & 2346.60 & 124 & & & \\
\hline \multirow[t]{3}{*}{ Amotivation } & $\begin{array}{l}\text { Between } \\
\text { Groups }\end{array}$ & 101.14 & 2 & 50.57 & \multirow{3}{*}{1.57} & \multirow{3}{*}{.21} \\
\hline & $\begin{array}{l}\text { Within } \\
\text { Groups }\end{array}$ & 3927.04 & 122 & \multirow[t]{2}{*}{32.18} & & \\
\hline & Total & 4028.19 & 124 & & & \\
\hline \multirow[t]{3}{*}{ Total } & $\begin{array}{l}\text { Between } \\
\text { Groups }\end{array}$ & 251.15 & 2 & 125.57 & \multirow{3}{*}{.21} & \multirow{3}{*}{.81} \\
\hline & $\begin{array}{l}\text { Within } \\
\text { Groups }\end{array}$ & 74678.84 & 122 & \multirow[t]{2}{*}{612.12} & & \\
\hline & Total & 74930.00 & 124 & & & \\
\hline
\end{tabular}

The relationship between students' online learning motivation strategies and their academic achievements is shown in Table 8. According to the findings, no significant difference was found between Intrinsic Motivation to Know ( $\mathrm{F}=.76 ; \mathrm{p}>.05)$; Intrinsic Motivation to Achieve $(\mathrm{F}=.95 ; \mathrm{p}>.05)$; Intrinsic Motivation to Experience Stimulation $(\mathrm{F}=1.13 ; \mathrm{p}>.05)$; Determined Regulation ( $\mathrm{F}=.50 ; \mathrm{p}>.05)$; Reflected Regulation $(\mathrm{F}=.54 ; \mathrm{p}>$.05); Amotivation ( $\mathrm{F}=1.57 ; \mathrm{p}>.05)$ and academic achievement. A significant difference was determined between the External Regulation and academic achievement $(\mathrm{F}=5.25 ; \mathrm{p}<.05)$. No significant difference was found between the online learning motivation total score and academic achievement $(\mathrm{F}=.21 ; \mathrm{p}>.05)$.

A significant difference was determined between External Regulation and academic achievement. According to the Scheffe test, it was seen that those with an academic achievement between 3 (2.51-3.00) and 4 (3.01-3.50) had higher External Regulation scores than those with an academic achievement of 5 (3.51-4.00). 


\section{a. their grades?}

Table 9. Descriptive Analysis Results of The Relationship Between Students' Online Learning Motivation and Grades

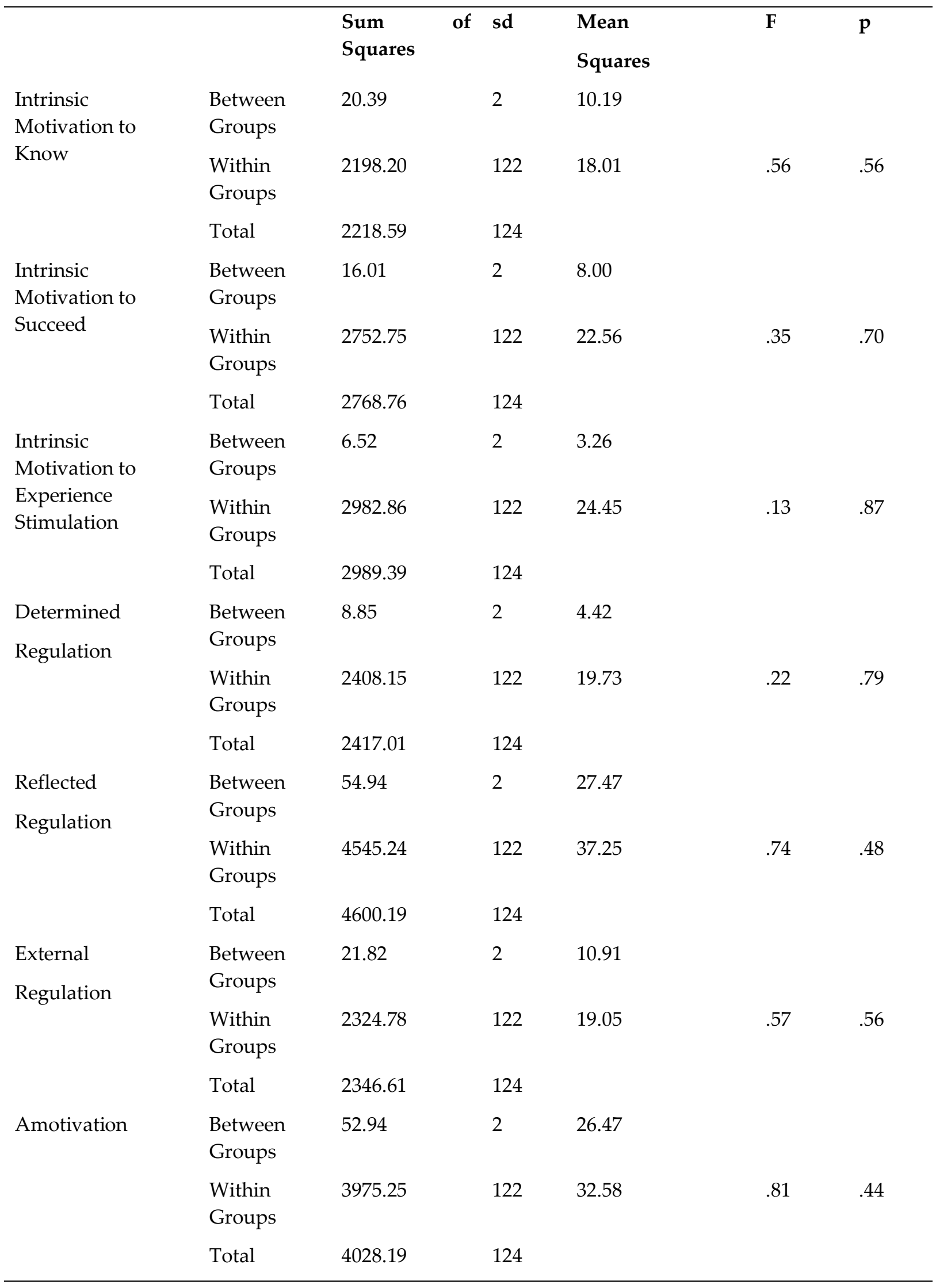




\begin{tabular}{lllllll}
\hline Total & Between & 67.04 & 2 & 33.51 & & \\
& Groups & & & & .05 & .94 \\
& Within & 74862.96 & 122 & 613.63 & & \\
Groups & & & & \\
& & & & \\
\hline
\end{tabular}

No significant difference was found between students' motivational strategies in online learning and their grade levels (Intrinsic Motivation to Know ( $\mathrm{F}=.56$; $\mathrm{p}>.05$ ); Intrinsic Motivation to Achieve ( $\mathrm{F}=.35 ; \mathrm{p}>.05)$; Intrinsic Motivation to Experience Stimulation) $(\mathrm{F}=$ 1.33; $\mathrm{p}>$.05); Determined Regulation ( $\mathrm{F}=.22 ; \mathrm{p}>.05)$; Reflected Regulation $(\mathrm{F}=.73 ; \mathrm{p}>.05)$; External Regulation $(\mathrm{F}=.57 ; \mathrm{p}>.05)$; Amotivation $(\mathrm{F}=.81 ; \mathrm{p}>.05)$. There was no significant difference between the total score of online learning motivation and grade levels $(\mathrm{F}=.05$; $\mathrm{p}>$ $.05)$.

\section{5) Do self-regulation strategies predict online learning motivation?}

The regression analysis was conducted to predict the level of self-regulation strategies of students in online learning motivation are given in Table 10.

Table 10. The Results of Regression Analysis

\begin{tabular}{llllll}
\hline $\begin{array}{l}\text { Predictor } \\
\text { Variable }\end{array}$ & $\mathrm{B}$ & Standart Error & $\beta$ (Beta) & $\mathrm{t}$ & $\mathrm{p}$ \\
Invariant & 2.706 & .191 & & & \\
Self-Regulated & .245 & .042 & .329 & 5.84 & .00 \\
$\mathbf{R}=.537$ & $\mathbf{R}^{2}=. \mathbf{2 8 8}$ & & & & \\
$\mathbf{F}(2-122)=38.05$ & $\mathbf{p}=.00$ & & & & \\
\hline
\end{tabular}

When Table 10 is examined, it was determined that self-regulation strategies in the online learning environment significantly predicted the motivation in the online learning environment $(\mathrm{t}=5.84 ; \mathrm{p}<.05)$. It was seen that students' self-regulation strategies in the online learning environment explained approximately $29 \%$ of the variance in online learning motivation $(\mathrm{R}=.537 ; \mathrm{R} 2=.288 ; \mathrm{F}=38.05 ; \mathrm{p}=.00)$.

\section{Discussion and Conclusion}

This study tries to shed light on learners' self-regulation learning strategies and motivational preferences in online learning process. Also, the study aims to investigate whether selfregulated learning strategies have a predictive role in online learning motivation. According to results, Cognitive Strategies, Affective Strategies, Meta Cognitive Strategies, MetaAffective Strategies related to the use of self-regulation strategies were at a high level and these strategies were used more; and these strategies were preferred mostly by female 
students. This means that these learners prefer to use strategies that help them construct, transform and apply knowledge during online learning. In addition, they need to create positive feelings and continuous motivation. Hence, these strategies provide cognitive information-processing mechanisms and having certain feelings, beliefs, attitudes, and motivations. The results of the study showed that Socio-Cultural Interactive Strategies were the strategy types which were related to the variables academic achievement and gender. It can be said that learners are able to learn through interaction and collaboration with others. They need to fill the gaps stemming from lacks in their knowledge by social interaction. This may explain the reason behind the level of academic achievement of learners. Online learning process may affect the academic achievement levels of learners in a negative way for the students who prefer Socio-Cultural Interactive Strategies. When, students' tendencies towards online learning motivation was examined, it was seen that students mostly used Intrinsic Motivation to Know ( $X=22.79)$. So, whatever the conditions, most learners were eager to know and learn. The results showed that they had the internal capacity for learning even if it is online.

It can be concluded from the study that self-regulated learning strategies have effect on online learning motivation of the students. In order to enhance motivational levels of learners during online learning, it is necessary to determine learner self-regulated learning strategy preferences. So, learning processes and materials may be arranged according to learners' self-regulated learning strategy preferences. In this manner, this provides us highly motivated learners in company with successful ones.

\section{Implications}

Self- regulation is the ability that helps learners manage and organize their thoughts and also convert them into skills which are necessary for learning. Self-regulation has "positive effects on behaviour and the acquisition of skills" (Reid, 1993, 48). It can contribute to educational and behavioural outcomes of learning process. If students are instructed for using selfregulated strategies in their learning process, they can take an active role in learning, have the motivation to participate and perform tasks independently. There is an intertwined relationship between self-regulation and motivation. During online learning process, students are mostly put in the driver's seat so, in order to be successful and academically competent students need self-regulation strategies accompanied by high learning motivation. 


\section{References}

Ally, M. (2008). Foundations of Educational Theory or Online Learning. In T. Anderson (Ed.), Theory and Practice of Online Learning (2nd Ed., Pp. 3-31). Retrieved From http://Www.Aupress.Ca/Index.Php/Books/120146.

Artino, A. R. (2008). Motivational Beliefs and Perceptions of Instructional Quality: Predicting Satisfaction with Online Training. Journal of Computer Assisted Learning, 24(3), 260-270. Doi: 10.1111/J.1365-2729.2007.00258.X

Banisaeid, M. \& Huang, J. (2015). The Role of Motivation in Self-Regulated Learning and Language Learning Strategy: In The Case of Chinese EFL Learners. International Journal of Applied Linguistics E English Literature, 4(5), 36-43.

Bekele, T. A. (2010). Motivation and Satisfaction in Internet-Supported Learning Environments: A Review. Educational Technology \& Society, 13 (2), 116-127.

Boekaerts, M. \& Minnaert, A. (2006). Affective and Motivational Outcomes of Working in Collaborative Groups. Educational Psychology, 26(2), 187-208. Doi: 10.1080/01443410500344217

Brophy, J. (2010). Motivating Students to Learn, (3rd Ed.). New York, NY: Routledge.

Dewey, J. (1913). Interest and Effort in Education. Boston, MA: Riverside Press.

Dörnyei, Z. (2005). The Psychology of the Language Learner: Individual Differences in Second Language Acquisition. Mahwah, N.J. L. Erlbaum.

Fischer, A. (1912). Die Faulheit [on Laziness]. ZeitschriftjR Pddagogische Psychologie und Experimentelle Peddagogik, 8, 507-516.

Flavell, J.H. (1978). Metacognitive Development. In J.M. Scandura, \& C.J. Brainerd (Eds.), Structural/Process Theories of Complex Human Behavior (Pp. 213-245). Alphen A.D. Rijn, Netherlands: Sijthoff and Noordhoff.

Gavriilidou, Z. \& Papanis, A. (2010). The Effect of Strategy Instruction on Strategy Use by Muslim Pupils Learning English as a Second Language. Journal of Applied Linguistics, 25, $47-63$.

Green, J. \& Oxford, R. L. (1995). A Close Look at Learning Strategies, L2 Proficiency, And Gender. TESOL Quarterly, 29, 261-297.

$\mathrm{Gu}$, Y. (2012). Learning Strategies: Prototypical Core and Dimensions of Variation. Studies in Self-Access Learning Journal, 3(4), 330-356.

Herbart, J. F. (1965). Allgemeine Piidagogik, Aus Dem Zweck Der Erziehung Abgeleitet [General Pedagogics, Deduced from the Purpose of Education]. In J. F. Herbart (Ed.), Piidagogische Schriften [Educational Scripts] (Pp. 9-155). Diisseldorf, Germany: Kiipper.

Keller, J. M. (2010). Motivational Design for Learning and Performance: The ARCS Model Approach. New York: Springer.

Dörnyei , Z. (2005). The psychology of the language learner: Individual differences in second language acquisition. Mahwah, N.J.: L. Erlbaum. 
Dündar, S. \& Köksal, D. (2017). Developing a Scale for Self-Regulated L2 Learning Strategy Use. Hacettepe University Journal of Education. 33. 1-16. 10.16986/HUJE.2017033805.

Lunk, G. (1926). Das Interesse [The Interest]. Leipzig, Germany: Klinkhardt.

Lynch, R. (2003). The Relationship between Academic Self-Regulation and Online Distance Education. Dissertation Abstract International, 64(12), 4432. (UMI No. 3116750)

Martens, R. L., Gulikers, J. \& Bastiaens, T. (2004). The Impact of Intrinsic Motivation on ELearning in Authentic Computer Tasks. Journal of Computer Assisted Learning, 20(5), 368376. Doi: 10.1111/J.1365-2729.2004.00096.X

Moore, M. G. (1989). Three Types of Interaction. American Journal of Distance Education, 3(2), 1-6. Doi: 10.1080/08923648909526659.

Nichols, M. (2008). E-Learning In Context - \#1. Eprimer Series. Retrieved From Ako Aotearoa Website Http://Akoaotearoa.Ac.Nz/Project/Eprimer-Series/Resources/Files/E-LearningContext-1-Eprimer-Series

Niemi, H., Nevgi, A, \& Virtanen, P. (2003). Towards Self-Regulation in Web-Based Learning. Journal of Educational Media, 28, 49-72.

Noels, K. A., Pelletier, L. G., Clément, R., \& Vallerand, R. J. (2000). Why are you learning a second language? motivational orientations and self-determination theory. Language Learning, 50, 57-85.

O'Malley, J. M., \& Chamot, A. U. (1990). Learning Strategies in Second Language Acquisition. Cambridge, England: Cambridge University Press.

Oxford, R. L. \& Burry-Stock, J. A. (1995). Assessing the Use of Language Learning Strategies Worldwide with the ESL/EFL Version of The Strategy Inventory for Language Learning (SILL). System, 23(1), 1-23.

Oxford, R. L. \& Nyikos, M. (1989). Variables Affecting Choice of Language Learning Strategies by University Students. Modern Language Journal, 73(3), 291-300.

Oxford, R. L. (1990). Language Learning Strategies: What Every Teacher Should Know. New York: Newbury House.

Oxford, R. L. (2011). Teaching And Researching Language Learning Strategies: Self-Regulation in Context (1st Edition). UK: Longman Pearson.

Oxford, R. L. (2017). Teaching And Researching Language Learning Strategies: Self-Regulation in Context (2nd Edition). NY: Routledge.

Özbaşı, D. \& Cevahir, H. \& Özdemir, M. (2018). Çevrimiçi Öğrenme Motivasyon Ölçeği'nin Türkçe'ye Uyarlanması: Geçerlik ve Güvenirlik Çalışması. Trakya Üniversitesi Eğitim Fakültesi Dergisi. 352-364. 10.24315/Trkefd.331973.

Panadero, E. (2017). A Review of Self-Regulated Learning: Six Models and Four Directions for Research. Frontiers in Psychology. 8.10.3389/Fpsyg.2017.00422.

Paris, S. G., \& Turner, J. C. (1994). Situated Motivation. In P. R. Pintrich, D. R. Brown \& C. E. Weinstein (Eds.), Student Motivation, Cognition, And Learning: Essays In Honor of Wilbert J. Mckeachie (Pp. 213-237). Hillsdale, NJ: Lawrence Erlbaum. 
Park, J.-H., \& Choi, H. J. (2009). Factors Influencing Adult Learners' Decision to Drop Out or Persist in Online Learning. Educational Technology \& Society, 12(4), 207-217. Retrieved From http://www.Ifets.Info/

Pintrich, P. R. \& Degroot, E. V. (1990). Motivational and Self-Regulated Learning Components of Classroom Academic Performance. Journal of Educational Psychology, 82, 33-40.

Pintrich, P. R. (2005). The Role of Goal Orientation in Self-Regulated Learning. In M. Boekaerts, P. R. Pintrich, And M. Zeidner (Eds.), Handbook of Self-Regulation, San Diego, CA: Academic, 451-502.

Platsidou, M. \& Kantaridou, Z. (2014). The Role of Attitudes and Learning Strategy Use in Predicting Perceived Competence in School-Aged Foreign Language Learners. Journal of Language and Literature, 5(3), 253-260.

Platsidou, M. \& Sipitanou, A. A. (2014). Exploring Relationships with Grade Level, Gender and Language Proficiency in the Foreign Language Learning Strategy Use of Children And Early Adolescents. International Journal of Research Studies in Language Learning, 4(1), 83-96.

Psaltou-Joycey, A. (2003). Strategy Use by Greek University Students of English. In E. MelaAthanasopoulou (Ed.), Selected Papers on Theoretical and Applied Linguistics of the $13^{\text {th }}$ International Symposium of Theoretical and Applied Linguistics. Thessaloniki: School of English, Aristotle University of Thessaloniki, 591-601.

Reid, R. (1993). Implementing self-monitoring interventions in the classroom: Lessons from research. Monograph in Behavior Disorders: Severe Behavior Disorders in Youth, 16, 43-54.

Rose, H. (2012). Reconceptualizing Strategic Learning in The Face of Self-Regulation: Throwing Language Learning Strategies out with the Bathwater. Journal of Applied Linguistics, 33(1), 92-98.

Ryan, R. M. \& Deci, E. L. (2000). Self-Determination Theory and the Facilitation of Intrinsic Motivation, Social Development, and Well-Being. American Psychologist, 55(1), 68.

Schunk, D. H., \& Usher, E. L. (2012). Social Cognitive Theory And Motivation. In R. M. Ryan (Ed.), The Oxford Handbook Of Human Motivation (Pp. 13-27). Oxford, UK: Oxford University Press.

Schunk, D. H, \& Zimmerman, B. J. (Eds.). (1998). Self-Regulated Learning: From Teaching To Self-Reflective Practice. New York: The Guilford Press.

Schunk, D. H. (2005). Self-Regulated Learning: The Educational Legacy of Paul R. Pintrich. Educational Psychologist, 40, 85-94.

Schunk, D. H., Meece, J. L., \& Pintrich, P. R. (2014). Motivation In Education: Theory, Research, And Applications (4th Ed.). Boston, MA: Pearson.

Shroff, R. \& Vogel, D. \& Coombes, J. \& Lee, F. (2007). Student E-Learning Intrinsic Motivation: A Qualitative Analysis. Communications of the Association for Information Systems. 19. 241-260. 10.17705/1CAIS.01912. 
Tseng, W. T., Dörnyei, Z. \& Schmitt, N. (2006). A New Approach to Assessing Strategic Learning: The Case of Self-Regulation in Vocabulary Acquisition. Applied Linguistics, 78102.

Whipp, J. L., \& Chiarelli, S. (2004). Self-Regulation in A Web-Based Course: A Case Study. Educational Technology Research \& Development, 52(4), 5-22. Doi: 10.1007/BF02504714

Wighting, M. J., Liu, J., \& Rovai, A. P. (2008). Distinguishing Sense of Community and Motivation Characteristics between Online and Traditional College Students. Quarterly Review of Distance Education, 9(3), 285-295.

Yukselturk, E., \& Bulut, S. (2007). Predictors for Student Success in an Online Course. Educational Technology \& Society, 10(2), 71-83. Retrieved From http://www.Ifets.Info/

Zimmerman, B. J. \& Schunk, D. H. (Eds.). (2001). Self-Regulated Learning and Academic Achievement: Theoretical Perspectives (2nd Ed.). Lawrence Erlbaum Associates Publishers.

Zimmerman, B. J. (1989). A Social Cognitive View of Self-Regulated Academic Learning. Journal of Educational Psychology, 81, 329-339. 